\title{
Do Multinational And Local Corporations Differ In Their Leverage Policies? Evidence From The MENA Region
}

Omar Farooq, American University in Cairo, Egypt

\begin{abstract}
This paper examines the leverage policies of multinational corporations (MNCs) in comparison to those of local corporations in the MENA region during the period between 2006 and 2012. Our results show that MNCs have lower leverage levels than local firms. We argue that MNCs have higher information asymmetries than other firms. As a result, managerial opportunism may be higher in these firms, thereby minimizing their ability to raise debt. In case of local firms, we show that their debt ratios are not different from other firms. Furthermore, we also show that our results do not hold for those multinational firms that have lower agency problems. We show that, for a given level of information asymmetries (operational and informational complexity), debt ratios of multinational firms are more than other firms. Our results show no impact of the extent of information asymmetries on debt ratios of local firms.
\end{abstract}

Keywords: Capital Structure; Multinational Firms; Local Firms; Information Asymmetries; Emerging Markets

\section{INTRODUCTION}

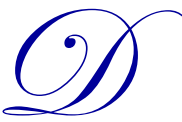

o multinational corporations (MNCs) differ from local firms in their capital structure? Does greater sophistication of MNCs lead them to raise more debt than local firms? Given that MNCs constitute an increasing proportion of global economic activity, capital structure policies adopted by MNCs have attracted considerable attention. Lee and Kwok (1988), for example, report that MNCs have lower leverage than local firms. They argue that MNCs have higher information asymmetries than their local counterparts. As a result, these firms are also prone to higher managerial opportunism. Given that higher debt introduces excessive monitoring by creditors, managers of MNCs tend to resist high leverage, thereby resulting in lower leverage in capital structure of MNCs. There is, however, another strand of literature that suggests the opposite. Chkir and Cosset (2001), for instance, document higher leverage for MNCs. They argue that geographic diversification of MNCs provide these firms with diversification benefit, thereby producing more stable cash flows and lowering the probability of default. Chkir and Cosset (2001) posit that lower default risk increases leverage on MNCs by allowing them to raise debt at more competitive rate.

Most of the prior studies on the comparison between capital structures of MNCs and local firms have been conducted on the data from relatively more developed markets. An important region that has failed to attract attention regarding this issue is the Middle East and North Africa (MENA). This paper is an attempt to fill this gap by documenting the relationship between the two in the MENA region (Morocco, Egypt, Jordan, Saudi Arabia, Kuwait, United Arab Emirates, Qatar, Oman, Tunisia, and Bahrain). The MENA region provides an interesting laboratory to conduct an analysis on the comparison of capital structures of MNCs and capital structures of local firms due to number of reasons. First, lower investor protection mechanisms in the MENA region increase the incentives for insiders to retain control, thereby making debt financing more preferred source of capital. However, it is not clear which of the two - MNCs or local firms - prefer debt over other sources of financing. Second, relatively lower development of stock markets in the MENA region also emasculates the ability of firms to raise external capital using public financial markets, thereby increasing the reliance on debt as a main source of capital. Again, it is not possible without empirical analysis to foresee which of the two - MNCs or local firms - will prefer debt more than the other. Third, and probably the most important reason pertains to the presence of concentrated ownership 
structures in the MENA region (Farooq and El Kacemi, 2011). Concentration of ownership increases the risk faced by controlling shareholders. Inability to diversify risk leads controlling shareholders to take those actions that can minimize non-diversifiable risks faced by them. One such action is reducing debt holdings of their firm. However, whether it is MNCs or local firms that prefer low leverage as a mechanism to reduce non-diversifiable risk is not clear.

Using various proxies of capital structure, this paper documents significantly lower leverage among MNCs relative to other firms in the MENA region during the period between 2006 and 2012. Our results, for instance, show that total debt to total equity ratio of MNCs is 21.1522 units less than other firms. Our results are consistent with arguments that associate higher information asymmetries with MNCs. Lee and Kwok (1988) argue that higher information asymmetries may lead to managerial opportunism in MNCs. Given that the higher levels of debt invite increased monitoring from creditors and lenders, managers may chose to have lower levels of debt to escape monitoring. Consequently, MNCs have lower levels of debt. Furthermore, we also show that the extent of information asymmetries (operational and informational complexity) have significant impact on the capital structure of MNCs. We show that, for a given level of information asymmetries, debt ratios of MNCs are higher than other firms.

The paper is structured as follows: Section 2 briefly discusses theoretical framework for this study. Section 3 describes the data and Section 4 provides assessment of our hypothesis. We discuss our results in Section 5 and the paper concludes with Section 6.

\section{HYPOTHESIS DEVELOPMENT}

Why Multinational (Local) Firms May Have Low (High) Leverage?

Prior literature cites plenty of arguments regarding lower leverage among MNCs. Some of them are as follows:

- Most important of them corresponds with increased information asymmetries associated with MNCs. Lee and Kwok (1988) suggests that it is more difficult to monitor firms that are globally active than those that are purely local. They argue that higher monitoring costs not only lead to greater conflict of interests between debt holders and shareholders but also translate into higher agency conflict between managers and shareholders. In another related study, Burgman (1996) argues that MNCs have higher information asymmetries due to institutional, legal, and socio-cultural differences across nations. We argue that increased information asymmetries, eventually, translate into more severe underinvestment problems in MNCs relative to local firms. Given that MNCs have higher information asymmetries for stakeholders including financial institutions, it is expected that they are offered a relatively higher debt rate than local firms. It will, therefore, lead MNCs to use retained earnings as a preferred source of financing, thereby reducing their leverage levels.

- Another reason that is frequently cited regarding lower leverage among MNCs pertains to increased profitability of MNCs relative to local firms. It is, generally, assumed that MNCs are bigger than local firms and are relatively more resourceful than local firms. Therefore, they have ability to generate more revenues. Moreover, their larger size gives them the opportunity for cost reductions through economies of scale which also leads to higher profitability. Higher profitability increases the reliance on retained earnings as a source of financing, thereby reducing the extent of leverage among MNCs.

- Geographic diversification exposes MNCs to exchange rate risk. We argue that if exchange rate changes pose substantial risk to MNCs by increasing the probability of financial distress, MNCs would avoid undertaking large debt. Therefore, they will have lower leverage than local firms. 
Why Multinational (Local) Firms May Have High (Low) Leverage?

Some of the reasons cited for higher leverage among MNCs are as follows:

- Compared to local firms that operate in a single economy, MNCs have operations in several economies. Performances of these economies are not perfectly correlated, thereby giving rise to diversification benefits for MNCs. Heston and Rouwenhorst (1994) document that diversification across political boundaries reduces risk more than diversifying across industries within one country. We argue that diversification benefits make the cash flows of MNCs more stable than other firms, thereby lowering the probability of default. When the probability of default goes down, it becomes easy to obtain debt at a competitive rate. Therefore, it is possible for MNCs to have higher debt ratios than local firms. Our arguments are consistent with Chkir and Cosset (2001) and Fatemi (1984) who posit that international diversification allows for increased debt capacity.

- Tax benefits differ from one country to the other. Given that MNCs operate in a diverse set of countries they have the flexibility to select the countries where it would operate with higher debt and where it would operate with lower debt. Therefore MNCs might have the ability to raise their leverage at will.

- MNCs are probably larger in size and have a tendency for pursuing larger projects with higher investment requirements. Therefore MNCs debt could be expected to be higher than local firms, especially if we consider that their transaction cost for acquiring debt is smaller. Furthermore, larger projects are expected to generate have higher levels of free cash flows for MNCs. Higher levels of free cash flows place abundant cash at the discretion of managers, thereby resulting in agency problems. Jensen and Meckling (1976) suggest that firms respond to high free cash flow by increasing debt to discipline managers. Consequently, we can expect MNCs to have higher levels of leverage.

- It is noted that if managers are better informed than capital markets, managers of undervalued firms prefer to forego projects, rather than issuing equity at below optimal prices. Given that MNCs have more information asymmetries than local firms, they may be undervalued. Therefore, equity issuance may not be an option for MNCs. We argue that MNCs will prefer to issue debt to reduce some of the information asymmetries, thereby resulting in higher leverage relative to local firms.

\section{DATA}

This paper documents the differences in capital structure policies of MNCs and local firms in the MENA region. The sample consists of all non-financial firms listed in Morocco, Egypt, Jordan, Saudi Arabia, Kuwait, United Arab Emirates, Qatar, Oman, Tunisia, and Bahrain during the period between 2006 and 2012. We consider these countries as the representative stock markets of the MENA region due to the availability of data. The following sub-sections will explain the data in more detail.

\section{Capital Structure}

This paper measures the capital structure by two variables: (1) Total debt to total asset ratio and (2) Total debt to total equity ratio. The data for the above mentioned variables is collected from the Worldscope. Table 1 documents the descriptive statistics for each variable during our sample period. We document relatively low level of debt in the region. For instance, Table 1 shows that total debt to total asset ratio is less than $20 \%$ across all years in the MENA region. Lower level of debt in the MENA region may be driven by a number of factors. For instance, most of listed firms have concentrated ownership structure in the MENA region (Farooq and El Kacemi, 2011). Concentrated ownership ties bulk of the wealth of controlling shareholders in a single investment. As a result, they are unable to fully diversify their risk (Maug, 1998). In order to minimize the risk of default, these shareholders may be reluctant to take on more debt. Furthermore, religious concerns may also discourage firms to take on more debt. Given that debt is prohibited in Islam and Islam is the dominant religion of the region, it is possible that firms decide not to take on excessive debt. 
Table 1. Descriptive statistics for capital structure

\begin{tabular}{lcc}
\hline Year & Total Debt / Common Equity (\%) & Total Debt / Total Assets (\%) \\
\hline 2006 & 60.3250 & 18.1043 \\
2007 & 58.1917 & 17.5260 \\
2008 & 63.7875 & 18.8637 \\
2009 & 62.0890 & 18.0461 \\
2010 & 60.3221 & 17.5807 \\
2011 & 61.6182 & 17.9136 \\
2012 & 60.5546 & 18.0101 \\
\hline
\end{tabular}

\section{MNCS and Local Firms}

Following Park et al. (2013), we define MNC as a firm that generates, at least, $20 \%$ of its sales from abroad. The local firm (LOCAL) is defined as a firm that generates $100 \%$ of its sales from within the country. Table 2 documents the descriptive statistics for MNCs and local firms during our sample period. As expected, we show that most of our sample firms are local firms. We also show that, on average, MNCs from the MENA region generate around $50 \%$ of their sales for abroad.

Table 2. Descriptive statistics for multinational firms and local firms

\begin{tabular}{ccccc}
\hline \multicolumn{3}{c}{ Foreign } & \multicolumn{2}{c}{ Local } \\
\hline Year & No. of Firms & Foreign Sales / Total Sale & No. of Firms & Foreign Sales / Total Sale \\
\hline 2006 & 56 & 47.1575 & 169 & 0.0000 \\
2007 & 63 & 50.9991 & 182 & 0.0000 \\
2008 & 75 & 57.0672 & 205 & 0.0000 \\
2009 & 86 & 56.3302 & 234 & 0.0000 \\
2010 & 99 & 55.5437 & 348 & 0.0000 \\
2011 & 97 & 57.7696 & 351 & 0.0000 \\
2012 & 117 & 56.9949 & 241 & 0.0000 \\
\hline
\end{tabular}

\section{Control Variables}

This paper uses a number of firm-specific characteristics as control variables. These variables are:

- SIZE: It is defined as log of firm's total assets. Prior literature presents conflicting evidence regarding the effect of size on capital structure. Booth et al. (2001) and Wiwattanakantang (1999) argue that larger firms are less prone to bankruptcy. Therefore, according to the trade-off theory, large firms have more debt in their capital structure. However, a large number of studies also report opposite results. Rajan and Zingales (1995), for instance, document that large firms have lower debt in their capital structure.

- GROWTH: It is defined as the growth in total assets over the last one year. It is expected that firms with high growth opportunities need more financing. Rajan and Zingales (1995) and Booth et al. (2001) document that firms with high growth opportunities have higher percentage of debt in their capital structure.

- EPS: It is defined as earnings per share. As was the case with size, earnings per share also has contradicting relationship with capital structure. The pecking order theory suggests that firms with higher earnings should use internal financing as the first sources for capital. Therefore, firms with high earnings should have lower debt in their capital structure (Booth et al., 2001; Chen, 2004; Chakraborty, 2010). However, according to the trade-off theory, firms with higher earnings have greater capacity to service debt. Therefore, we expect a positive relationship between earnings per share and the amount of debt in capital structure.

- RoA: It is defined as return on total assets. Trade-off theory argues that profitability pushes firms to have high debt ratios. Given that profitable firms have lower expected costs of bankruptcy, they should issue more debt. 
We obtain the date for the above mentioned variables from the Worldscope. Table 3 documents the descriptive statistics (Panel A) and the correlation matrix (Panel B) for our control variables. Table 3, Panel A, reports no big difference in means and medians for our control variables. The only exception is EPS whose median is very close to zero. It suggests that most of the firms in our dataset were not very profitable. Our results in Table 3, Panel B, show no severe correlations between our control variables. Therefore, we can include all the variables together in any regression equation.

Table 3. Statistics for control variables

Panel A. Descriptive statistics for control variables

\begin{tabular}{|c|c|c|}
\hline Variables & Mean & Median \\
\hline SIZE & 12.4340 & 12.2434 \\
\hline GROWTH & 15.8061 & 8.7250 \\
\hline EPS & 2.6120 & 0.1550 \\
\hline RoA & 5.1500 & 4.7600 \\
\hline
\end{tabular}

Panel B. Correlation matrix for control variables

\begin{tabular}{lcccc}
\hline \multicolumn{1}{c}{ Variables } & Size & Growth & EPS & RoA \\
\hline SIZE & 1.0000 & & & \\
GROWTH & 0.0282 & 1.0000 & 1.0000 & \\
EPS & 0.2060 & -0.0162 & 0.1878 & 1.0000 \\
RoA & 0.0302 & 0.1063 & \\
\hline
\end{tabular}

\section{METHODOLOGY}

This section tests whether there exists any difference between the capital structure of MNCs and the capital structure of local firms in the MENA region. In order to test this conjecture, we estimate the following regression equation with capital structure (LEV) as a dependent variable and two dummy variables representing multinational firms (MNC) and local firms (LOCAL) as independent variables. MNC takes the value of 1 , if firm has at least $20 \%$ of its sales from abroad and 0 otherwise. LOCAL takes the value of 1 , if firm has $100 \%$ of its sales from within the country and 0 otherwise. We would like to mention here that there will be no perfect multicollinearity due to the presence of a third group whose foreign sales are between $0 \%$ and $20 \%$ of total sales. Furthermore, we also add a number of variables as control variables in our regression equation. As defined earlier, these variables are: SIZE, GROWTH, EPS, and RoA. It is important to mention here that we use panel data regression with fixed effects for our analysis. Hausman test is used to decide between fixed effect and random effects. We will run the following regression for the two proxies of capital structure (total debt to total asset ratio and total debt to total equity) as defined above.

$$
\begin{aligned}
& \mathrm{LEV}=\alpha+\beta_{1}(\mathrm{MNC})+\beta_{2}(\mathrm{LOCAL}) \\
& +\beta_{3}(\mathrm{SIZE})+\beta_{4}(\mathrm{GROWTH})+\beta_{5}(\mathrm{EPS})+\beta_{6}(\mathrm{ROA})+\varepsilon
\end{aligned}
$$

The results of our analysis are reported in Table 4. Our results suggest that MNCs have significantly lower total debt to total equity ratio than other firms. We report significantly negative coefficient estimate of MNC. Our results show that total debt to total equity ratio of MNCs is 21.1522 units less than other firms. Our results are consistent with prior literature that suggests higher information asymmetries for multinational firms (Burgman, 1996; Lee and Kwok, 1988). Higher information asymmetries may lead to more managerial opportunism in multinational firms. Given that the higher levels of debt invite increased monitoring from creditors and lenders, managers may chose to have lower levels of debt to escape monitoring. Consequently, we should observe lower levels of debt in multinational firms. However, our result turn insignificant when total debt to total asset ratio is used as a proxy for capital structure. In this case, we report insignificantly coefficient estimate of MNC. Our results also show that local firms do not differ from other firms in their capital structure. We report insignificant coefficient of LOCAL for both proxies of capital structure. 
Table 4. Differences between the capital structure of multinational firms and the capital structure of local firms

\begin{tabular}{l|cc|cc}
\hline \multicolumn{1}{c|}{ Variables } & \multicolumn{2}{c|}{ Total Debt / Common Equity } & \multicolumn{2}{c}{ Total Debt / Total Assets } \\
\hline MNC & $-20.0242^{*}$ & $-21.1522^{*}$ & 0.5176 & 0.6653 \\
LOCAL & 7.1153 & 4.4705 & -1.0659 & -0.9540 \\
\hline SIZE & $36.6479^{* * *}$ & $35.4840^{* * *}$ & $5.1756^{* * *}$ & $5.0823^{* * *}$ \\
GROWTH & -0.0363 & -0.0315 & 0.0046 & 0.0043 \\
EPS & -0.1304 & -0.1778 & 0.0230 & 0.0229 \\
RoA & $-3.5331^{* * *}$ & $-3.5427 * * *$ & $-0.3143 * * *$ & $-0.3152^{* * *}$ \\
\hline Fixed Effects & No & Yes & No & Yes \\
\hline No. of Observations & 3666 & 3666 & 3764 & 3764 \\
No. of Groups & 685 & 685 & 687 & 687 \\
F-Value & 2.02 & 2.96 & 15.27 & 10.13 \\
R ${ }^{2}$-within & 0.0256 & 0.0281 & 0.1171 & 0.1197 \\
\hline
\end{tabular}

Note: The coefficients with $1 \%$ significance are followed by ***, coefficient with $5 \%$ by **, and coefficients with $10 \%$ by *.

There may be concerns that the results documented in Table 4 are confined to certain stocks. In order to overcome this concern, we split our sample into two groups, one group with size higher than the median and the other with size lower than the median. We re-estimate Equation (1) for both sub-samples. The results of our analysis are reported in Table 5. Our results show that our results hold only in small multinational firms. We report lower total debt to total equity ratio for small multinational firms than other small firms. We document significantly negative coefficient estimate of MNC for this group. Our results show that total debt to total equity ratio of multinational firms is 21.9967 units less than other small firms. In case of total debt to total asset ratio, we report that large local firms have higher leverage than other large firms. We report significantly positive coefficient estimate of LOCAL for this group. Our results also show that big MNCs do not differ from other firms in their capital structure. We report insignificantly coefficient estimate of MNC for this group.

Table 5. Differences between the capital structure of multinational firms and the capital structure of local firms in sub-samples of small and large firms

\begin{tabular}{l|cc|cc}
\hline \multirow{2}{*}{\multicolumn{1}{c}{ Variables }} & \multicolumn{2}{c|}{ Total Debt / Common Equity } & \multicolumn{2}{c}{ Total Debt / Total Assets } \\
\cline { 2 - 5 } & Small Firms & Large Firms & Small Firms & Large Firms \\
\hline MNC & $-21.9967^{*}$ & -23.1924 & -1.8756 & -0.9462 \\
LOCAL & 6.7703 & 3.3303 & $1.5055^{*}$ & 0.2412 \\
\hline SIZE & $18.7635^{*}$ & $46.6426^{* * *}$ & $5.0650^{* *}$ & $6.5329^{* * *}$ \\
GROWTH & -0.0549 & -0.0230 & -0.0006 & $0.0107^{* * *}$ \\
EPS & $10.2672^{* *}$ & 0.1426 & $2.7802^{* * *}$ & 0.0263 \\
RoA & $-1.4521^{* * *}$ & $-5.3917 * *$ & $-0.2911 * * *$ & $-0.3541^{* * *}$ \\
\hline Fixed Effects & No & Yes & No & Yes \\
\hline No. of Observations & 981 & 2685 & 985 & 2689 \\
No. of Groups & 232 & 505 & 234 & 505 \\
F-Value & 2.21 & 3.40 & 3.43 & 8.69 \\
R ${ }^{2}$-within & 0.0454 & 0.0367 & 0.1247 & 0.1476 \\
\hline
\end{tabular}

Note: The coefficients with $1 \%$ significance are followed by ***, coefficient with $5 \%$ by **, and coefficients with $10 \%$ by *.

\section{DISCUSSION OF RESULTS}

Effect of Agency Problems On the Differences Between the Capital Structure of Multinational Firms and the Capital Structure of Local Firms

Our results have shown that MNCs headquartered in the MENA region have relatively lower level of leverage in their capital structure than local firms. Prior literature argues that MNCs have low leverage because of agency costs or the underinvestment problem (Burgman, 1996; Doukas and Pantzalis, 2003; Lee and Kwok, 1988). In this section, we document the impact of agency problems on the capital structure of MNCs. Controlling for agency problems should be able to increase the ability of MNCs to acquire more debt. In order to address this conjecture, we re-estimate the above regression equation after adding three variables, COMP, MNC*COMP, and LOCAL*COMP. We define COMP as the ratio of salary expenses to total operating expenses. Prior literature argues that COMP reflects operational and informational complexity of a firm (Abdel-Khalik, 1993; Hay and Davis, 2004). Knechel et al. (2008) argue that an increasing amount of operational and informational complexity gives rise to 
moral hazard problems between management and minority shareholders. They also note that management has broader scope to control and thus manipulate information in firms with high complexity. Our modified regression equation takes the following form:

$$
\begin{aligned}
& \text { LEV }=\alpha+\beta_{1}(\mathrm{MNC})+\beta_{2}(\mathrm{LOCAL}) \\
& +\beta_{3}(\mathrm{COMP})+\beta_{4}(\mathrm{MNC} * \mathrm{COMP})+\beta_{5}(\mathrm{LOCAL} * \mathrm{COMP}) \\
& +\beta_{6}(\mathrm{SIZE})+\beta_{7}(\mathrm{GROWTH})+\beta_{8}(\mathrm{EPS})+\beta_{9}(\mathrm{RoA})+\varepsilon
\end{aligned}
$$

The results of our analysis are reported in Table 6. Interestingly, our results show that for a given level of operational and informational complexity, MNCs have higher leverage than other firms. We report significantly positive coefficient of MNC*COMP. Our results show that, for a given level of complexity, total debt to total asset ratio of MNCs is 22.7650 units more than other firms. The result holds true for both proxies (total debt to total asset ratio and total debt to common equity ratio) of capital structure. Our results indicate that once we control for agency conflicts, managerial opportunism goes down. Consequently, managers find it more appealing to issue debt. Our arguments are supported by prior literature that considers information asymmetries associated with MNCs as the main reason behind lower leverage in these firms (Burgman, 1996; Lee and Kwok, 1988). This strand of literature argues that information asymmetries manifest themselves via increased managerial opportunism. However, for those MNCs that have lower agency problem, there is no reason to resist debt issuance. As a result, these MNCs have higher leverage in their capital structure. In case of local firms, we show no impact of impact of agency problems on capital structure. We report insignificantly coefficient of LOCAL*COMP.

\begin{tabular}{|c|c|c|c|c|}
\hline Variables & Total Deb & on Equity & Total De & Assets \\
\hline MNC & $-39.9162 * *$ & $-43.4840 * *$ & $-4.6275^{* *}$ & $-4.0576^{*}$ \\
\hline LOCAL & -3.2604 & -8.5783 & 0.2273 & 0.7410 \\
\hline COMP & -38.2022 & -49.8618 & -4.3266 & -3.7413 \\
\hline MNC*COMP & $107.8467 * *$ & $118.1912^{* *}$ & $22.4739 * *$ & $22.7650 * * *$ \\
\hline LOCAL*COMP & 39.1051 & 50.0296 & -0.0182 & -0.0174 \\
\hline SIZE & $39.3218 * *$ & $38.3166^{* * *}$ & $4.8472 * * *$ & $6.5226^{* * *}$ \\
\hline GROWTH & -0.0450 & -0.0393 & $0.0112^{*}$ & $0.0100^{*}$ \\
\hline EPS & 0.0036 & -0.0503 & 0.0568 & 0.0578 \\
\hline RoA & $-4.2645 * *$ & $-4.2792 * *$ & $-0.3227 * * *$ & $-0.3568 * * *$ \\
\hline Fixed Effects & No & Yes & No & Yes \\
\hline No. of Observations & 3156 & 3156 & 1387 & 1387 \\
\hline No. of Groups & 655 & 655 & 490 & 490 \\
\hline F-Value & 2.75 & 2.31 & 5.11 & 4.45 \\
\hline $\mathrm{R}^{2}$-within & 0.0287 & 0.0323 & 0.1391 & 0.1530 \\
\hline
\end{tabular}

Table 6. Effect of operational complexity on the differences between the capital structure of multinational firms and the capital structure of local firms

Note: The coefficients with $1 \%$ significance are followed by $* * *$, coefficient with $5 \%$ by ${ }^{* *}$, and coefficients with $10 \%$ by $*$.

\section{Implications of Differences in Capital Structure On the Performance of Multinational Firms and Local Firms}

Prior literature argues that lower leverage in capital structure of MNCs is due to higher agency problems present in these firms (Doukas and Pantzalis, 2003). This strand of literature also argues that some of these agency problems can be offset by acquiring more leverage (Jensen and Meckling, 1976). We argue that high agency problems may lead to lower performance of MNCs relative to local firms. However, with acquisition of more debt, performance of MNCs is supposed to improve relative to local firms due to reduction in information asymmetries. In order to test these arguments, we estimate the following regression with firm performance (RET) as an independent variable. RET is the market-adjusted return and is defined as the difference between gross returns and market returns. Our regression equation takes the following form:

$$
\begin{aligned}
& \mathrm{RET}=\alpha+\beta_{1}(\mathrm{MNC})+\beta_{2}(\mathrm{LOCAL}) \\
& +\beta_{3}(\mathrm{LEV})+\beta_{4}(\mathrm{MNC} * \mathrm{LEV})+\beta_{5}(\mathrm{LOCAL} * \mathrm{LEV}) \\
& +\beta_{6}(\mathrm{SIZE})+\beta_{7}(\mathrm{GROWTH})+\beta_{8}(\mathrm{EPS})+\beta_{9}(\mathrm{RoA})+\varepsilon
\end{aligned}
$$


The results of our analysis are reported in Table 7. Our results show that, on average, MNCs underperform local firms in the MENA region. We report higher coefficients of LOCAL for most of equations relative to MNC. Our result is intuitive in a way that MNCs are supposed to have high information asymmetries. High information asymmetries, usually, translate into lower performance (Mitton, 2002). Our result also shows that leverage is associated with better performance in the MENA region. We report significantly positive coefficient of LEV for all equations. Surprisingly, we also show that when MNCs take on more debt, their performance tends to go down. We report significantly negative coefficient of MNC*LEV for all equations. Increased leverage is supposed to reduce agency problems and increase firm performance. However, it is not the case for MNCs in the MENA region. Behavior of MNCs is in contrast to the behavior of local firms whose performance remains unaffected as the extent of leverage in their capital structure goes up. We report insignificant coefficient of LOCAL*LEV for all equations.

Table 7. Implications of differences in capital structure on the on the performance of multinational firms and local firms

\begin{tabular}{l|cc|cc}
\hline \multicolumn{1}{c|}{ Variables } & \multicolumn{2}{c|}{ Total Debt / Common Equity } & \multicolumn{2}{c}{ Total Debt / Total Assets } \\
\hline MNC & $0.0795^{*}$ & 0.0487 & $0.1423^{* * *}$ & $0.0820^{*}$ \\
LOCAL & $0.0858^{* * *}$ & $0.0873^{* * *}$ & $0.0993^{* * *}$ & $0.1004^{* * *}$ \\
\hline LEVERAGE & $0.0008^{* *}$ & $0.0009^{* *}$ & $0.0027^{*}$ & $0.0030^{* *}$ \\
\hline MNC*LEVERAGE & $-0.0012^{* * *}$ & $-0.0011^{* * *}$ & $-0.0063^{* * *}$ & $-0.0048^{* * *}$ \\
LOCAL*LEVERAGE & -0.0002 & -0.0002 & -0.0015 & -0.0013 \\
\hline SIZE & -0.0212 & $-0.1336^{* * *}$ & -0.0229 & $-0.1247^{* * *}$ \\
GROWTH & $0.0009^{* * *}$ & $0.0012^{* * *}$ & $0.0009^{* *}$ & $0.0011^{* *}$ \\
EPS & 0.0007 & 0.0018 & 0.0007 & 0.0018 \\
RoA & $0.0139^{* * *}$ & $0.0115^{* * *}$ & $0.0133^{* * *}$ & $0.0108^{* * *}$ \\
\hline Fixed Effects & No & Yes & No & Yes \\
\hline No. of Observations & 3439 & 3439 & 3513 & 3513 \\
No. of Groups & 653 & 653 & 660 & 660 \\
F-Value & 10.41 & 45.17 & 0.58 & 45.75 \\
R ${ }^{2}$-within & 0.0507 & 0.2533 & 0.0498 & 0.2509 \\
\hline Note: The coefficients with $1 \%$ significance are followed by $* * *$, coefficient with $5 \%$ by $* *$ and coefficients with $10^{*}$ by $*$
\end{tabular}

\section{CONCLUSION}

This paper documents the difference between capital structures of multinational and local firms in the MENA region during the period between 2006 and 2012. Our results show that multinational firms tend to have low debt ratios (as measured by total debt to total asset ratio and total debt to total equity ratio) than other firms. Prior literature argues that multinational firms have higher information asymmetries than other firms. As a result, managerial opportunism may be higher in these firms, thereby minimizing the ability of these firms to raise debt. In case of local firms, our results indicate that their debt ratios are not different from other firms. Furthermore, we show that our result does not hold for those multinational firms that have lower agency problems. Our results also show that, for a given level of information asymmetries (operational and informational complexity), debt ratios of multinational firms are more than other firms. Our results show no impact of the extent of information asymmetries on debt ratios of local firms.

\section{REFERENCES}

Abdel-Khalik, A. R., (1993). Why do Private Companies Demand Auditing? A Case for Organizational Loss of Control. Journal of Accounting, Auditing and Finance, 8(1), pp. 31-52.

Booth, L., Aivazian, V., Demirguc-Kunt, A., and Maksimovic, V., (2001). Capital Structure in Developing Countries. Journal of Finance, 56(1), pp. 87-130.

Burgman, T. A., (1996). An Empirical Examination of Multinational Corporate Capital Structure. Journal of International Business Studies, 27(3), pp. 553-570.

Chakraborty, I., (2010). Capital Structure in an Emerging Stock Market: The Case of India. Research in International Business and Finance, 24(3), pp. 295-314.

Chen, J. J., (2004). Determinants of Capital Structure of Chinese-listed Companies. Journal of Business Research, 57(12), pp. 1341-1351.

Chkir, I. E., and Cosset, J. (2001). Diversification Strategy and Capital Structure of Multinational Corporations. Journal of Multinational Financial Management, 11(1), pp. 17-37.

Doukas, J. A. and Pantzalis, C., (2003). Geographical Diversification and Agency Costs of Debt of Multinational Firms. Journal of Corporate Finance, 9(1), pp. 59-92. 
Farooq, O. and El Kacemi, Y., (2011). Ownership Concentration, Choice of Auditors, and Firm Performance: Evidence from the MENA Region. Review of Middle East Economics and Finance, 7(2), pp. 1-17.

Fatemi, A. M., (1988). The Effect of International Diversification on Corporate Financing Policy. Journal of Business Research, 16(1). pp. 17-30.

Hay, D., and Davis, D., (2004). The Voluntary Choice of an Auditor of Any Level of Quality. Auditing: A Journal of Practice and Theory, 23(2), pp. 37-53.

Heston, S. and Rouwenhorst, G. (1994). Does Industrial Structure Explain the Benefits of International Diversification? Journal of Financial Economics 36(1), pp. 3-27.

Jensen, M. and Meckling, W., (1976). Theory of the Firm, Managerial Behavior, Agency Costs, and Ownership Structure. Journal of Financial Economics, 3(4), pp. 305-360.

Knechel, W. R., Niemi, L., and Sundgren, S., (2008). Determinants of Auditor Choice: Evidence from a Small Client Market. International Journal of Auditing, 12(1), pp. 65-88.

Lee, K. C. and Kwok, C. Y., (1988). Multinational Corporations vs. Domestic Corporations: International Environmental Factors and Determinants of Capital Structure. Journal of International Business Studies, 19(2), pp. 195-217.

Maug, E., (1998). Large Shareholders as Monitors: Is There a Trade-Off between Liquidity and Control? Journal of Finance, 53(1), pp. 65-98.

Mitton, T., (2002). A Cross-firm Analysis of the Impact of Corporate Governance on the East Asian Financial Crisis. Journal of Financial Economics, 64(2), pp. 215-244.

Park, S. H., Suh, J., and Yeung, B., (2013). Do Multinational and Domestic Corporations Differ in their Leverage Policies? Journal of Corporate Finance, 20, pp. 115-139.

Rajan R., and Zingales, L., (1995). What Do We Know About Capital Structure? Some Evidence from International Data. Journal of Finance, 50(1), pp. 1421-1460.

Wiwattanakantang, Y., (1999). An Empirical Study on the Determinants of the Capital Structure of Thai Firms. Pacific-Basin Finance Journal, 7(3-4), pp. 371-403. 


\section{NOTES}

